Article

\title{
"We Demand Better Ways to Communicate": Pre-Digital Media Practices in Refugee Camps
}

\author{
Philipp Seuferling \\ Media and Communication Studies, Södertörn University, 14189 Huddinge, Sweden; E-Mail: philipp.seuferling@sh.se
}

Submitted: 11 December 2018 | Accepted: 7 March 2019 | Published: 28 June 2019

\begin{abstract}
This article provides a historical perspective on media practices in refugee camps. Through an analysis of archival material emerging from refugee camps in Germany between 1945 and 2000, roles and functions of media practices in the camp experience among forced migrants are demonstrated. The refugee camp is conceptualized as a heterotopian space, where media practices took place in pre-digital media environments. The archival records show how media practices of refugees responded to the spatial constraints of the camp. At the same time, media practices emerged from the precarious power relations between refugees, administration, and activists. Opportunities, spaces, and access to media practices and technologies were provided, yet at the same time restricted, by the camp structure and administration, as well as created by refugees and volunteers. Media activist practices, such as the voicing of demands for the availability of media, demonstrate how access to media was fought for within the power structures and affordances of the analogue environment. While basic media infrastructure had to be fought for more than in the digital era and surveillance and control of media practices was more intense, the basic need for access to information and connectivity was similar in pre-digital times, resulting in media activism. This exploration of unconsidered technological environments in media and refugee studies can arguably nuance our understanding of the role of media technologies in "refugee crises".
\end{abstract}

\section{Keywords}

communication history; forced migration; Germany; media activism; media practices; refugee camp

\section{Issue}

This article is part of the issue "Refugee Crises Disclosed: Intersections between Media, Communication and Forced Migration Processes", edited by Vasiliki Tsagkroni (Leiden University, The Netherlands) and Amanda Alencar (Erasmus University Rotterdam, The Netherlands).

(C) 2019 by the author; licensee Cogitatio (Lisbon, Portugal). This article is licensed under a Creative Commons Attribution 4.0 International License (CC BY).

\section{Introduction}

It is not new to postulate that media and communication are central to experiences of forced migration. Information scarcity, contact with loved ones left behind, and general disorientation associated with displacement are experiences, which entail mediated practices and are dependent on various forms of communication. Digital media, especially the smartphone, are often described as new empowering tools to navigate the complexities of seeking and finding asylum. Often, the focus lies on identifying practices, experiences, and problems, which had not been possible before.

This article intends to question, debunk, and relativize the alleged newness of media practices forced mi- grants engage with. Forced migration is older than the Internet, which flags up the question of how different media technologies have engendered media practices amidst refugees in similar or different ways. The aim of this article is, therefore, to identify explicitly pre-digital media practices in refugee camps in Germany, between 1945 and 2000. Drawing on archival material from this empirical context, traces of pre-digital media practices among refugees are analyzed, in order to explore how different media practices have emerged from the camp.

The refugee camp represents a continuity of the modern refugee regime, a spatial construct of sovereignty and control grown out of the countless displacements during the 20th and 21st centuries (Gatrell, 2013). Within these enduring spaces, I argue, we can fruitfully 
observe changes and continuities of analogue and digital media practices across longer periods of time. Therefore, I am suggesting an exploration of camp-based refugee media practices, which is removed from a digital-only focus and avoids the daunting rhetoric of "digital exceptionalism" (Marwick, 2013). By using the admittedly problematic term "pre-digital", I do not want to draw another techno-centred periodical border and reinforce the meaning of the digital, yet widen scholarly attention to unconsidered technological environments, when analyzing the communication situations of refugees.

Ample research has scrutinized refugees' media practices. The "connected migrant" maintaining a "culture of bonds" (Diminescu, 2008) has been the subject of the emerging field of "digital migration studies" (Leurs \& Smets, 2018), evaluating ramifications of digital technologies in fleeing, waiting, arriving, and integrating (Alencar, 2018; Gillespie, Osseiran, \& Cheesman, 2018; Graf, 2018; Leurs, 2017; Twigt, 2018, Witteborn, 2014a). Within the refugee camp, media experiences have been described as "information precarity" (Wall, Campbell, \& Janbek, 2017), and as spaces of instability and uncertainty, where media provide ontological security (Smets, 2018) and are used to manage (im)perceptibility (Witteborn, 2014b). While these studies provide useful concepts, for the most part, they do not consider the historical trajectories of pre-digital media environments. Digging backwards is a crucial undertaking in media and refugee studies if we want to avoid overestimating the significance of new digital media. Therefore, the following research questions are posed: which media practices emerged from the predigital spatial setting of the refugee camp? How did the camps' power structures enable or disable forms of communication? How were the needs and functions of media practices fulfilled in pre-digital times?

Sections 2 and 3 outline the conceptual avenues into historicizing media practices (Couldry, 2004), and theorize the camp as a heterotopian space (Foucault, 1997). The camp is understood as a controlled space of the modern refugee regime (Gatrell, 2013), where refugees draw on different media practices to cope with, comply with, or resist and circumvent the power structures which are imposed upon them. In Section 4, the methods are summarized and background information on refugee camps in Germany between 1945 and 2000 is provided. The empirical analysis in Sections 5 and 6 identifies heterotopian media practices within the space of the camp, produced by a triad of actors: residents, administration, and volunteers/activists. It is demonstrated how media practices responded to the heterotopian conditions, resulting in media activist practices within the limitations of space and power.

\section{Media Practices in Refugee Camps-Historical Avenues}

"[T]he history of media is never more or less than the history of their uses, which always lead us away from them to the social practices and conflicts they illuminate" states Carolyn Marvin (1990, p. 8). Pre-digital media practices in refugee camps elucidate such marginal "social practices and conflicts" and are thus entry points to the histories of media and communication. In research about media and forced migration, diachronic historical perspectives are vital interventions to the often presentist and digital-centred accounts of media within "refugeedom" (Gatrell, 2017). Peter Gatrell (2017, p. 170) defines "refugeedom" as a "matrix involving administrative practices, legal norms, social relations, and refugees' experiences, as well as highlighting how these have been represented in cultural terms". I argue that media practices are part of such historically constructed and produced refugeedom frameworks. Media technologies have both co-produced refugeedom and can be used by refugees to counteract and resist it. Part of refugeedom is the refugee camp, a symptom of the modern refugee regime, created to control the legal figure of the refugee (Gatrell, 2013). It is a materialized "modern social imaginary" in the words of Charles Taylor (2004), where belongings and exclusions in society are imagined and produced. Therefore, as a specific intersection of media and communication history and refugee studies, this article focusses on media practices in the refugee camp.

The concept of "media practices", most eminently described by Nick Couldry, captures any lose, yet interrelated set of open-ended practices "oriented towards media and the role of media in ordering other practices in the social world" (Couldry, 2004, p. 115). Shifting attention to actions in relation to media allows for interrelational understandings of media and other social practices and their mutual influencing. This "decenter[ing of] media research from the study of media texts" (p. 117) is well suited to situate the refugee and their agency within the material and discursive power structures that camp internment produces. A media practice approach not only includes what people do with media but also what they "say in relation to media" (Couldry, 2010 , p. 41). The inclusion of mediated discourses and imaginaries around the roles and functions of media technologies in the refugee camp is methodically helpful when seeking historical avenues. I grasp archival records as traces of media practices in the camp, including all kinds of mediated or media-influenced social practices, discourses, and imaginaries emerging from the camp (cf. similar methodologies in Gitelman, 2006; Marvin, 1990; Kaun, 2016).

Hence, an inquiry of "the open-ended range of practices focused directly or indirectly on media" (Couldry, 2004 , p. 117) is a way to uncover the roles and functions of media and communication in pre-digital refugee camps. The examples below will map some of these, focusing especially on media activism (Mattoni, 2012; Pickard \& Yang, 2017) and the voicing of demands as a media practice. In research on refugees and media, this approach to what refugees do with digital media has been recognised, too, as outlined above. However, to 
contextualize the specificities of the digital, and to serve justice to the longue durée of forced migration and camp accommodation, we need to include empirical material that stands outside the digital.

\section{The Heterotopian Space of the Refugee Camp}

Refugees accommodated in camps are, spatially and socially, at the margins of media and communication and their histories. Yet, the camp produces a space, which, from the refugees' perspective, is a centre of communication. To understand the spatiality of the camp and how it affects media and communication, it has to be seen as a materially produced, and socially constructed, communicative space, where media practices take place; they are embedded into the spatial structures provided by the camp (cf. Despard, 2016).

In Germany, the regime at refugee camps and shelters has become ever tighter over the years (Gatrell, 2013). If all legal categories of forced migrants created in the post-WW2 refugee regime are counted, hundreds of thousands of refugees, expellees, asylum-seekers, or displaced persons have lived in a camp structure in Germany at some point ${ }^{1}$. These bureaucratic legal definitions, which "make" the figure of the refugee (Gatrell, 2013), are tied to the space of the camp, which controls forced migrants in space and time. Thereby, it is a "social imaginary" (Taylor, 2004), materializing the refugee regime.

To further comprehend how the spatial regime of the camp and media practices intersect, I draw on Foucault's (1997) notion of heterotopias, reading it as a space which enables new practices, politics, and agencies within the power dynamics of its control regimes. Heterotopias are arrangements of spaces with a function in society:

[A] counter arrangement, of effectively realized utopia, in which....all the other real arrangements that can be found within society, are at one and the same time represented, challenged, and overturned: a sort of place that lies outside all places and yet is actually localizable. (p. 333)

Refugee camps are exactly these "absolutely other" spaces, created to uphold the refugee regime, and are thus "occupied by individuals whose behaviour deviates from the current average or standard" (p. 333), namely the "national order of things" (Malkki, 1995). Thus, they are heterotopias of deviation. The camps' function is to stand in an othering relation to the rest of spaces, by being an institutionalized space, which expresses inclusion and exclusion from the "normal", national society, by putting the refugees into forced immobility. Their function of separating people during the long wait of the asylum-seeking process also creates a heterotopian tem- porality of the space, or "heterochronism", which works for the refugees as a "total breach of their traditional time" (Foucault, 1997, p. 334). Ultimately, Foucault describes the heterotopian condition as "one thinks one has entered and, by the sole fact of entering, one is excluded" (p. 335), which holds true in a very literal sense for the refugees accommodated in camps.

Still, these spaces can actually be found at the centre of societies, of cities, and rural areas, and thus coconstruct utopian imaginaries of (dis)belonging. What does this mean for media practices within the camps? On account that citizenship and political agency are constrained within the refugee regime, other practices have to be employed. As scholarship within refugee studies shows, for refugees, camps have been sites of community-building, a first safe haven, or transitory home, where new identity performances in situations of social arrest and uncertainty have taken place (Malkki, 1996; McLaren, 2010; Turner, 2016).

Media practices are part of these experiences of camp internment, and I, therefore, suggest that they should be understood as heterotopian, too. Firstly, a focus on media practices points at possibilities of agency and political engagement, emerging from the heterotopian space. Media can facilitate articulation and selforganization, of course within the power constraints of the camp and the refugee regime. In this sense, heterotopian media practices respond to the necessities and limitations that the space creates. They are extremely space-related in this context, as they emerge from the heterotopian conditions as outlined above. They are dependent on access to technology within the camp, or on permission only being granted for their use in certain rooms, as well as on the inherent limitations, such as lack of information and connectivity, which internment and immobility produce. Thereby, they are reactions to the heterotopia's functions of separating "deviants", creating new temporal regimes, and othering its occupants into exclusion and invisibility.

Heterotopias "always presuppose a system of opening and closing that isolates them and makes them penetrable at one and the same time" (Foucault, 1997, p. 335). Refugee camps are not fully closed entities, certain practices and actors penetrate its boundaries. Media practices are communicatory forms of challenging this spatial regime, of crossing its fences and the refugee regime. The fight for connectivity and ways of communication, often in collaboration with activists and NGOs from outside, are such practices grown out of the heterotopian condition. For the occupants, the goal of certain media practices is hence to make the space less heterotopian, so to speak, to integrate it with the "normal" spaces around the camp through forms of mediated communication, as well as to fight the state of deviation and otherness.

\footnotetext{
${ }^{1}$ For the sake of readability, yet being aware of its problematic, the term "refugee camp" will be used for all state-run accommodation structures for refugees and asylum-seekers. "Refugee" will equally be used in an all-encompassing sense for all forced migrants, asylum-seekers and refugees, not in its legal sense as having gained refugee status.
} 
According to this reading of heterotopias, I want to argue that refugee camps are spaces which enact institutionalized power and undermine citizenship, yet they also provide space for practices, which act against such regimes of control, and emerge from the heterotopian condition. Heterotopian media practices are simultaneously tied to the limitations that the refugee regime produces within the camp space, as well as the subversive forms of negotiating different strategies to be able to cope with the traumatizing experiences of forced migration, internment, and immobility in the camp.

\section{Methods and Cases}

The archive material analyzed ranges from administrative documents to leaflets and magazines produced by refugees, volunteers, and activists; material included printed interviews, letters, photos, statistical data, minutes from meetings, as well as other sources (see archives in references). The files are archived in relation to a range of different refugee camps in West Germany and were chosen for analysis if they referred to any kind of media practice, as defined above. Qualitative content analysis was employed. The content of the files was categorized according to different forms of media practices (e.g., access to technology, need for connectivity, creation of public sphere etc.). This open coding was boiled down into repetitive concepts. I understand the sources as traces of media practices, which both give insights into discourses and imaginaries around roles and functions of media technologies and provide documentation of actual practices. While being, of course, incomplete and dependent on successful preservation, the variety of sources incorporates governmental sources from the top (State Archives) as well as refugees' and activists' voices from below (Archive for Social Movements). When combined, they complement each other and show the refugee regime as well as the resistance against it.

Refugee camps in West Germany from 1945 up to 2000 are representative of the Western refugee regime. First established in response to mass expulsions of WW1, refurbished after WW2, camp structures were developed further and are still intact today (Gatrell, 2013, p. 5). A multitude of legal regimes created different categories of refugee statuses in both German states, adapted to the respective political contexts. Camps ranged from large camps, almost suburban-like structures for post-WW2 expellees and refugees (who had German citizenship), to more closed institutions for foreign refugees, for example, from Hungary in 1956, or Vietnam and different African and Middle Eastern countries, or the Balkans, in the 1980s and 1990s. In these cases, the refugees had to dwell in institutionalized accommodation, while their asylum claims were processed. Unlike many camps in the Middle East or Africa, the structures were provided by the German state and strictly managed by authorities on site. Social benefits, legal procedures, food, and clothing supplies were organized there and were dependent on exact legislation and the status of the refugee (e.g., asylum-seeker with a pending case, accepted refugee, quota refugee, rejected but tolerated refugee). Changing terminologies reveal evolving political discourses and the tightening of the refugee regime, starting from "Flüchtlingslager" (refugee camp), to "Zentrale Anlaufstelle (ZASt)" (central contact point), "Notaufnahmelager" (emergency reception camp), "Durchgangslager" (transit camp), the derogative "Asylantenheim" (asylum-seeker camp), up to the now still common "Gemeinschaftsunterkunft" (common accommodation). Several thousand of these institutions existed in Germany across the time frame (Beer, 2014). Different laws regulated rights and duties, being revised multiple times into stricter versions with fewer benefits. For foreign asylum-seekers, separated accommodation in camps was set as a deliberate goal in the late 1970s and early 1980s. In East Germany, camps existed for returnees from the West as well as for Communist war refugees, for example, from Greece; they are however not considered in this article.

Living conditions in the camps were highly dependent on these legal regimes (see for overview Hochmuth \& Bispinck, 2014; Neubauer, 1995). The architecture of the structures ranged from reused concentration camps, army barracks or simple huts, repurposed hotels or halls, to multiple-family houses or even village-like structures. As housing and administration of refugees are organized at the local level in Germany's federal system, a general account of camp conditions is impossible. However, we know from contemporary reports that conditions were dire. Refugees dwelled mostly in single or shared rooms, or small flats for families, living off a small monthly allowance, benefits in kind, or coupons. Food was either provided three times a day (usually in camps of first arrival, where the regime was often unaware of the various religions and nationalities of the refugees) or had to be cooked by the refugees themselves (in longer-term accommodation). For foreign refugees, working was usually forbidden. Often, staff from social charity organizations, or volunteers and activists, would provide points of contact with the outside world for the refugees, organizing leisure activities or providing legal counselling. Refugees were free to leave the camps, however, the district or commune could not be left. Often hygiene, fire safety, and general conditions were bad, mental health problems and suicide were normal. These dire conditions incorporated precarious privacy, and constant surveillance during long periods of waiting and doing nothing. A refugee, quoted in the source material, described it like this: "When you are an asylum-seeker, you live like in prison, but in prison, you can work a little. Not here, only eat and sleep and do bullshit" (Arbeitsgruppe Asylpolitik des Dritte Welt e.V., 1991; all quotes translated by the author).

In 1983, UNHCR filed a report about the conditions in West Germany's refugee camps (Refugee Survey Quarterly, 2008). The so-called "Toscani-report" heavily criticized the poor conditions in the seven camps that were 
visited, causing a minor diplomatic row with the German government. The report clearly links specific policies in relation to the camps and asylum-processing to the bad performance in categories such as staff, community work, hygiene, legal counselling and mental health etc. They called out racist structures and concluded that "it was difficult to imagine how bad the conditions actually are in the centres in the FRG without actually seeing them" (Refugee Survey Quarterly, 2008, p. 163).

Within this context, the material collected points to a diverse range of media practices, including interpersonal contact with family and friends elsewhere, attempts to attain information and access to news, practices of witnessing and remembering, or practices of media activism in the form of voicing demands. Of course, these practices happen today, too. Yet, in pre-digital media environments, they had to be crafted and carried out by other means, leading to different power dynamics. The subsequent examples will firstly analyze how the heterotopian space of the camp affected media practices, and secondly how media activist practices, or the voicing of demands for and through media, emerged from the heterotopian condition as a prevalent practice in predigital times.

\section{Media Practices in the Heterotopia}

Unsurprisingly, camp-based refugees faced an extreme situation of information scarcity in pre-digital media environments as they do today. Responding to the lack of connectivity, instead of hunting signal or Wi-Fi, both refugees and camp administration found alternative media technologies.

In 1952, several refugee camps in West Berlin, accommodating refugees from the GDR, received 65 radios as a donation from the public service broadcaster NWDR in Hamburg. Previously, a government official had asked for the devices in a letter, describing how the lack of radios and news magazines created one of the biggest hardships: "being cut off from the outside world hits the inmates of the camps especially hard", the donation would be an "act of utmost philanthropy" (Eichler, 1952). The imaginaries around the functions of media technology put forward in this letter exchange show how access to information was deemed essential within the confines of the camp and its information precarity. Radio was the only medium at the time that could receive live broadcasts across national borders. Photos show how transistor radios in particular (and later portable TV-sets) were regular features in the refugees' private rooms so that broadcasts from their home countries could be listened to. Radios often were one of the first things newcomers would buy or trade within the camps.

The archival records demonstrate how media and communication opportunities were tied to the physical and architectural structures of the camps, they were included in the spatial conditions or invented in response to them. The transistor radios acted as mobile devices do today as they could easily be taken in case of relocation. A different kind of space-related media practice in the camp can be observed in the creation of designated spaces for communication: e.g. camp cinemas in the 1940s and 1950s, showing newsreels and light entertainment; or TV, radio and newspaper rooms as social gathering rooms. These are reminiscent of today's "Internet rooms", which Saskia Witteborn analyzes as sites for media use. They enable "technologically mediated sociality" (2014a, p. 356), by combining media use and the physical sharing of space to socialize. These possibilities were offered by the camp administration, this offering, however, enabled full control and surveillance of where and when certain media practices could take place. For example, in the so-called Valka-camp in Nuremberg, the main camp for foreigners after WW2, different cinema providers competed for time slots to play their films in the "theatre barracks". A letter from the camp manager to the government reveals that they closely scrutinized the selection of films, as they wanted to boost morale and democratic education among the residents, whereas the providers often brought popular, light entertainment movies (Gewerbebetriebe im Sammellager für Ausländer und Kantinen Allgemein, ca. 1950-1960).

In cases where spaces for specific necessary media practices were missing, this gap could often be filled by an alternative, as Figure 1 shows. Creatively improvising with the means at hand, camp residents in Friedland (1940s/1950s) developed a paper-based way of exchanging information, by posting small sheets of paper on the walls of the huts, mostly trying to find lost family members and friends. The walls and improvised blackboards became communication hubs, an exchange platform for information within and beyond the camp, for information which was desperately needed during the post-war disorientation. With time, these search ads switched medium and became a regular part of a West German radio program, where names and contact details of lost individuals were read out (Wagner, 2014).

Communication spaces and opportunities for media practices were both offered from above, by the camp structures and administration, thereby materializing the refugee regime in place-but also created from below, by the refugees themselves, often supported by volunteers and activists. Possibilities for media practices were a power play between these actors. They responded to the heterotopian condition, both through its othering and excluding dimension that created information precarity, as well as through the creative invention of other media practices which were necessary and responded to the spatial constraints.

If we move to the later context of the 1980s and 1990 s, when the asylum legislation had been significantly tightened, camp accommodation was made obligatory for all newcomers, work was prohibited, long waiting times were the norm, and when racist attacks proliferated, we can also see that the control of media practices became stricter. Cinemas or other media-related spaces 


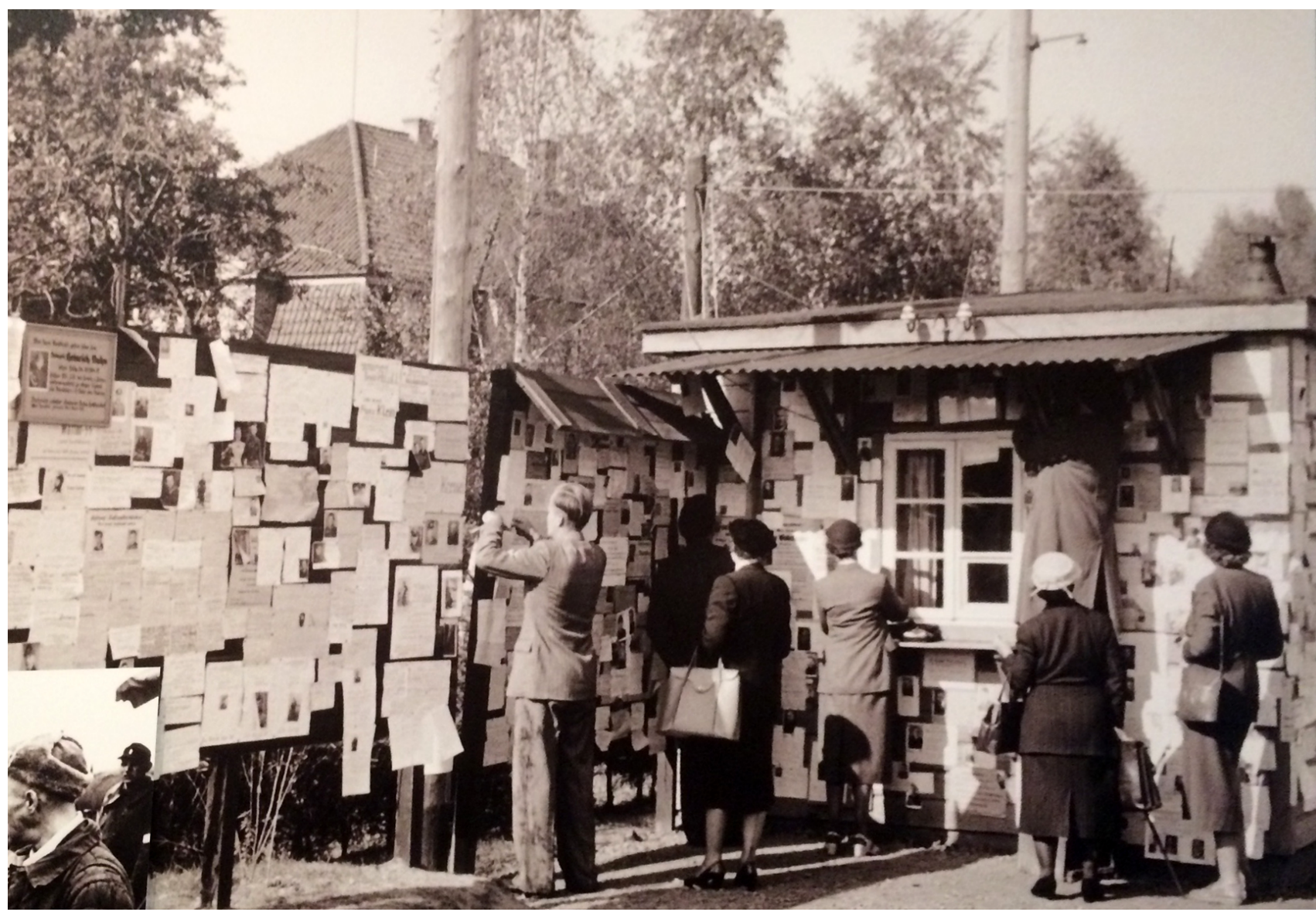

Figure 1. Camp residents in Friedland communicating via blackboards and walls of the camp buildings (৫ Museum Friedland).

were no longer generally available. Only a few references in camps' house rules or inventory lists show that "newspapers in national language" or a TV-room were provided, (Gemeinschaftsunterkünfte und Flüchtlingswohnheime im Regierungsbezirk Braunschweig. 1982-1987, ca. 1982-1987). Media was no longer part of the basic provision and, in the case of camp telephones, the use of this communication technology was often even explicitly forbidden, or only granted in emergencies.

In this situation of high information precarity, the sources reveal the role of volunteers and activists in fighting for, enabling, as well as engaging in media practices for and with the refugees. Often stemming from a leftwing, anti-racist milieu, but also from Christian circles, they interacted with the heterotopian space from outside, stepping in to help:

Incentives by us helpers to take over the flow of information inside the camp, were deemed positively. They need our material and personal support for that. To proceed in that, the refugees want a space outside the camp to meet. (Gruppe gegen Rassismus, 1993)

As the previous examples have already shown, the control of media practices in the camp was subject to struggle. Imaginaries and ascribed functions of media tech- nologies show how access to certain information and media practices, be it news, legal counselling, entertainment, or personal contacts, is managed within and through space. In the example, activists and refugees fight to transgress the borders of the camp: A physical space outside the camp to manage information flows avoids control inside. In another case in Freiburg, volunteers created an "info café" in a student dorm outside the camp, enabling unsupervised distance and free speech for the refugees (UnterstützerInnengruppe, 1994). Similarly, a letter exchange from 1992 between a volunteer and the camp administration demonstrates that the struggle around access to media technologies was also a struggle to obtain opportunities for socializing and wellbeing. The activist group suggested to establish a "tearoom" in the camp:

Refugees are dependent on up-to-date information from their home countries. This information has to reach the refugees - especially during the first months -in their mother tongue. Therefore, we want to offer them newspapers in several languages. Our idea is that the camp Blankenburg offers us a room for two hours per week. The reading time could then be a meeting point for refugees, including coffee and tea. (Zahedi \& Walterfang, 1992) 
Access to basic information, which today would be delivered through apps, probably used in their rooms, was fought for within the complicated power and communication structures of the camp. In the pre-digital media environment, the need for connectivity was filled by spatial solutions, by places and spaces where certain media practices counteracted information scarcity. In the case of the tea room, however, the reply from the camp manager was a two-page letter, listing bureaucratic reasons why such a tea-room would be completely impossible. He encouraged the volunteers to find facilities outside the camp, adding in a smug tone that it would offer the refugees a "meaningful alternative to their daily stroll around the city's shops" (Zahedi \& Walterfang, 1992). Unlike the initial example of the radio donations in 1952, communication possibilities were again actively prevented by the camp administration.

This first step of the analysis shows how media practices were embedded in the heterotopian spatial structure of the camp, within and beyond its fences, circling around three central actors: refugees, administration and staff, as well as activists, situated within the systemic power structures of the refugee regime. Their media practices are both reproducing and contesting the heterotopia, using the possibilities of predigital media, and responding to these spatial and social power constraints.

\section{Fighting out of the Heterotopia: Media Activist Practices}

The heterotopian space of the camp affects the needs and functions of media technologies and respective practices. The examples so far have shown that spatial and power structures affect how pre-digital media practices could be enacted, but also how new practices became necessary. Especially, practices of protest, contention and critique against the effects of the refugee regime are discernible across the materials which were analyzed. These practices are closely tied to media practices and can be examined as media activist practices (Mattoni, 2012; Pickard \& Yang, 2017).

The use of media in pre-digital camps was a question of availability and dependent on power structures the triangle of actors created. As media practices had to be actively fought for, they can be understood as intertwined forms of media activism, a concept from social movement studies, grasping the use of media and communication by activists (Pickard \& Yang, 2017, pp. 1-5). Activists develop "repertoires of communication" (Mattoni, 2013), which include sets of media practices employed for specific purposes of mobilization.

In this context, I want to demonstrate how both the fight for media technology, i.e. the possibility of media practices, but also the voicing of critique and demands within the refugee regime, were forms of media activism. This includes media practices by both refugees and volunteers, which were used to fight for connectivity, access to media, or the re-negotiating power structures of communication and information in the camp.

As a first example for the negotiation of media practices, camp assemblies of refugees and administration served as a platform for the voicing of demands and critique. Preserved reports show how amidst general problems, such as food, accommodation, or permissions, media practices were also debated:

Transcript of the discussion with the Hungarian refugees in the transition camp Finkenwerder, Friday, 11 January 1957....German newspapers and magazines are requested. The question if Hungarian music etc. is wished for, is strongly denied. They wish to be acquainted with German culture. Film screenings once a week like in other camps. (Finkenwerder Ungarnflüchtlinge, ca. 1956-1960)

These general assemblies were enacted public spheres within the camps, a form of communication themselves, and a forum for debating media practices, such as access to newspapers etc. Another source from 1993 documents how an assembly was pushed for by the refugees, after a letter with the refugees' demands was handed over to the management (Gruppe gegen Rassismus, 1993). Such demand lists or open letters, formulated by the camp residents, often (linguistically and practically) supported by activists, are well-preserved in the material. Their purpose was to create publicity and awareness of conditions in the camp and were often passed to the press. Concrete issues were protests against deportations, experiences of racism and abuse, bad living conditions and health care, but also the lack of connectivity and the fight for media:

Public declaration of the refugees in the camp....The 280 refugees living there don't even have a phone booth to contact family and friends. There are no common rooms, where refugees could meet and socialize, read, or watch TV (UnterstützerInnengruppe, 1994)

List of shortcomings by Iranian women....There is no library, no newspapers. Radios are missing and a TV (a few have private devices), the TV room is always locked, almost all devices are broken, they are not repaired....Too few telephones, only four booths, not enough for all residents. (Anderes lernen e.V., 1996)

Demand lists, often handed over at assemblies, are a form of political action, of fighting for and re-negotiating power in the heterotopia. They document conditions in the camp, by mediating them and making them available to broader audiences beyond the camp. In Friedland, refugees even elected representatives, who would manage communication with the administration. In the pre-digital environment, paper-based lists, open letters, leaflets or magazines were the main form of media activist practices emerging from the camps. These 
were one part of the refugees' and activists' "repertoire of communication" (Mattoni, 2013). Connected to this repertoire are other magazines, documentation and reports of camp life or of camp visits, photo collections or even exhibitions, mostly emerging from the activist scene. Under titles such as "I don't know if I can ever laugh again. Bosnian refugees in Hermannsburg tell their stories" (Runder Tisch Hermannsburg, 1994) or "18 weeks of refugee struggle, Neumünster, Greifswald, Norderstedt. A documentation" (Autonome Info Gruppe Kiel, 1992), conditions and voices in the camps were made public. These represent another goal of media activist practices; aiming to show the public and provide insight into the neglected space of the camp as well as to give witness to the refugees' experiences. In analogue media environments possibilities for refugees to have a voice and to create publicity themselves, to managing their perceptibility (Witteborn, 2014b) and to create new "reclaimant narratives" (Bishop, 2018) against negative media coverage, were mostly restricted to paper-based documentation. The invitation of mass media representatives or politicians into the camp was part of this tactic of presenting the problems of camp accommodation to wider circles to foster support.

The story of one concrete camp exemplifies in more detail, what has been elaborated so far. The "Hotel Astoria" in Göttingen had been repurposed as an asylumseeker accommodation from 1982 to 1991. Due to its generally awful conditions, it quickly turned into a notorious "cauldron of unrest...from which the virus of resistance spread" (Arbeitsgruppe Asylpolitik des Dritte Welt e.V., 1991). The camp was permanently in the press for changing managers (in total 7), including one case of sexual abuse and a very negative report by the health department. Usually, around 130 refugees from 18 different nationalities lived in the "hotel". Things culminated in February 1986 when the residents decided to boycott the in-house grocery shop. The local asylum law had changed the benefits from cash to coupons, following a "principle of material goods". The refugees announced their protest firstly against the shop, which sold overpriced food that had gone off, and secondly, demanded to receive their benefits in cash. A demonstration was organized, leaflets and a protest-telegram informed politicians, media, and the general public. On 6 February, they entered an open-ended hunger strike. The residents had been heavily supported by a local activist group, and during the hunger strike even UNHCR heard about the situation, expressed their support and called for the end of the coupon policy. On 12 February, a camp assembly was held with visiting politicians, the refugees, the mass media, and activists, providing an opportunity for a heated debate about the situation. Further protests against the coupon-system were organized, including a system in which activists would buy food and coupons from the refugees, meaning they effectively got cash. It was ended in 1987. The hotel burned down in 1989 and was finally closed in 1991.
This short history of this specific case illustrates how in the pre-digital era, media activism was created in reaction to the specific (awful) conditions of the space. Especially, the creation of publicity, including interactions with mass media (here, different local newspapers and the public-service broadcaster NDR), was a common practice of high importance, as visibility and publicity successfully created pressure to improve conditions. Leaflets, open letters and demand lists by refugees, activists, and even the social workers in the camp document the protests as traces of media practices. Many preserved newspaper articles document the mediated discourse about this specific camp, sometimes including voices of refugees, who tried to affect narratives and perceptions about themselves, e.g. in interviews in activist magazines or newspapers (cf. Bishop, 2018). The examples illustrate specifically "relational media practices", which Mattoni (2013, pp. 48-50) describes as adapted, tailored interactions with media technologies, outlets and professionals, that activists engage in. Here, the specific technologies of dissemination have been chosen to create both publicity in different circles and communication against the powerful actors in the administration.

The range of examples shows how pre-digital media activist practices have been fostered by the heterotopian space of the refugee camp. The lack of connectivity and other dire conditions which the refugee regime produces have been responded to through media activist practices, as a form of heterotopian media practices. They can be mapped into different categories, fighting for different rights. Firstly, different demands were mediated in the form of paper-based or telegraphed lists and open letters, but also in the production of wider-circulated magazines or leaflets. These media practices were mainly addressing the bad living conditions in the camps, fighting for the right of humane treatment. Secondly, the possibility of media practices themselves was fought for, the necessary media infrastructure. When asking for "better ways of communication" (Gruppe gegen Rassismus, 1993), the right to communication was to be achieved, just as today e.g. hacker activists help to set up Wi-Fi networks in refugee camps (Kubitschko \& Schütz, 2016). And thirdly, through the creation of media, which could cross the boundaries of the camp, injustices and experiences, such as the clear lack of media and information or the horrendous costs of phone calls, could be made public, and protests could be documented (e.g. in the case of hunger strikes). Interviews with refugees were published in magazines, everyday life was documented, but much more importantly, mass media were included to create visibility and political pressure. Media activist practices hence helped to push these voices outside of the camp, and mediate and document them, when general information precarity hampered self-articulation and media use in the way we know it from digital technologies today. These media practices ought to support a right to appropriate representation. 


\section{Conclusion}

This article has showcased historical trajectories to "refugee crises" and their interrelation to media and communication. The refugee camp is a space and place, where roles and functions of media in forced migration can be studied historically. It is where analogue and digital media have been used, imagined, fought for, or created-responding to evolving refugee regimes and media environments in a heterotopian space.

In pre-digital media environments of refugee camps in West Germany, media practices were dependent on spatial and social power structures, created and subverted by camp administration, refugees, and activists. Opportunities, spaces, and access to and for media practices and respective technologies were provided, yet at the same time restricted, by the camp structure and administration, as well as fought for and created by refugees and volunteers. Heterotopian media practices emerged, which responded to the spatial restrictions and conditions, which the refugee regime had put the refugees in. In the earlier post-war period and 1950s, material spaces for media and communication, such as camp cinemas, were the norm and opportunities for media practices were created by the administration. By the 1980s and 1990s, media technology was no longer a part of a camp's inventory and possibilities for media practices had to be achieved much more actively. In response to the lack of connectivity and access to media, media activist practices, especially the mediated voicing of demands and the creation of public awareness as media practices, demonstrate how "communication rights" (Leurs, 2017) were fought for; they happened both within the power structures of the refugee regime, and the affordances of the analogue environment. The appropriation of different ways of communicating and the struggle for access to media technologies adapted to the needs of those fighting against information precarity. As a heterotopia, the camp's pre-digital media environment was both maintained control and social arrest, while being undermined by media activism. The media practices analyzed show how the heterotopian conditions of exclusion, othering and deviation were counteracted by drawing upon mediated communication to render the space visible to the wider world and connect it to spaces within the surrounding society. The different actors manoeuvred around the limited temporal and spatial affordances of pre-digital media within the space of the camp, trying to traverse it. Although Koen Leurs' (2017) concept of "communication rights", based on young refugees' smartphone use, focuses on the digital, it provides a perspective on agency, but also on political, social, and cultural limitations affecting refugees' media practices. Digging back into the pre-digital era has shown how communication rights have also been fought for in the past. Media technologies, such as telephones, radios, newspapers, but also letters, magazines, and leaflets, were drawn upon to obtain news, reach loved-ones, or create visibility and give witness to the oppressive structures of the refugee regime. If these findings are compared to the categories describing "information precarity" (Wall et al., 2017) today, it becomes clear that basic media infrastructures had to be established first to be able to access any information, but also to individually mediate communication. This created more direct threats of surveillance and social control by the administration, to enable them to prevent media practices. However, the general experiences of information insecurity-or even the mere lack of any media technology-are very similar, regardless of the technological environment. And moreover, both historically and today, these experiences are reacted to with specific media (activist) practices.

Ultimately, this article shows that it is exactly through this historical insight into the fight for media practices, that the functions and conflicts around media and communication within the heterotopian space of the refugee camp become visible. Of course, this is only a first step to pinpoint the historical trajectories of media practices within forced migration contexts and more detailed discussion, for example, around dimensions of gender or race, are needed, and must be methodically combined with oral history interviews. However, as this first study shows, historical perspectives allow us to reconfigure our understanding of digital media and ask which new problems and opportunities they have really put forward in the realm of forced migration today. We can ask more rigorously whether some of these experiences and problems have already been solved in the past, or even whether certain problems have rather emerged from other, not directly media-related historical contexts of ever-evolving refugee regimes.

\section{Acknowledgments}

I wish to thank the anonymous reviewers, as well as my supervisors Heike Graf, Anne Kaun and Staffan Ericson for their helpful comments throughout the work on this article.

\section{Conflict of Interests}

The author declares no conflict of interests.

\section{References}

Alencar, A. (2018). Refugee integration and social media: A local and experiential perspective. Information Communication and Society, 21(11), 1588-1603.

Anderes lernen e.V. (1996). Flüchtlingsleben, Beispiel Lübeck [Refugee life, example Lübeck]. (04.210). Archive for Social Movements, Hamburg, Germany.

Arbeitsgruppe Asylpolitik des Dritte Welt e.V. (1991). Hotel Astoria. Geschichte eines Sammellagers 1982-1991 [Hotel Astoria. History of a Camp 1982-1991]. (04.500). Archive for Social Move- 
ments, Hamburg, Germany.

Autonome Info Gruppe Kiel. (1992). 18 Wochen Flüchtlingskampf, Neumünster, Greifswald, Norderstedt. Eine Dokumentation [18 weeks of refugee struggle, Neumünster, Greifswald, Norderstedt. A documentation]. (04.153). Archive for Social Movements, Hamburg, Germany.

Beer, M. (2014). Die deutsche Nachkriegszeit als Lagergeschichte-Zur Funktion von Flüchtlingslagern im Prozess der Eingliederung [The German post-war time as a history of camps-On the function of refugee camps in integration processes]. In $\mathrm{K}$. Hochmuth \& H. Bispinck (Eds.), Flüchtlingslager im Nachkriegsdeutschland. Migration, Politik, Erinnerung [Refugee camps in post-war Germany. Migration, politics, memory] (pp. 47-71). Berlin: Christoph Links Verlag.

Bishop, S. (2018). "Nobody can take our story": Competing representational narratives of immigrants without legal status. Communication \& Society, 31(3), 159-173.

Couldry, N. (2004). Theorising media as practice. Social Semiotics, 14(2), 115-132.

Couldry, N. (2010). Theorising media as practice. In B. Bräuchler \& J. Postill (Eds.), Theorising media and practice (pp. 35-54). New York, NY: Berghahn Books.

Despard, E. (2016). A materialist media ecological approach to studying urban media in/of place. In S. Kubitschko \& A. Kaun (Eds.), Innovative methods in media and communication studies (pp. 37-58). Cham: Palgrave Macmillan.

Diminescu, D. (2008). The connected migrant: An epistemological manifesto. Social Science Information, 47(4), 565-579.

Eichler, W. (1952, February 18). Letter from Willi Eichler (SPD Berlin) to Adolf Grimme (director of NWDR). (621-1/144, NDR.11_712). State Archive Hamburg, Hamburg, Germany.

Finkenwerder Ungarnflüchtlinge [Finkenwerder Hungarian refugees]. [ca. 1956-1960]. [Collection]. (4427_219). State Archive Hamburg, Hamburg, Germany.

Foucault, M. (1997). Of other spaces: Utopias and heterotopias. In N. Leach (Ed.), Rethinking architecture: A reader in cultural theory (pp. 350-356). New York, NY: Routledge.

Gatrell, P. (2013). The making of the modern refugee. Oxford: Oxford University Press.

Gatrell, P. (2017). Refugees-What's wrong with history? Journal of Refugee Studies, 30(2), 170-189.

Gemeinschaftsunterkünfte und Flüchtlingswohnheime im Regierungsbezirk Braunschweig. 1982-1987 [Communal accommodations and refugee housing in the district of Braunschweig. 1982-1987]. [ca. 1982-1987]. (NDS 380 Acc. 2014/012 Nr. 55). Lower Saxony State Archive, Hannover, Germany.

Gewerbebetriebe im Sammellager für Ausländer und Kantinen Allgemein [Businesses in the camp for foreigners and cantines in general]. [ca. 1950-1960].
[Collection]. (StAN Reg. v. Mfr. Abg. 1978, Nr. 19856). Bavarian State Archives, Nuremberg, Germany.

Gillespie, M., Osseiran, S., \& Cheesman, M. (2018). Syrian refugees and the digital passage to Europe: Smartphone infrastructures and affordances. Social Media + Society, 4(1), 1-12.

Gitelman, L. (2006). Always already new. Media, history, and the data of culture. Cambridge, MA: MIT Press.

Graf, H. (2018). Media practices and forced migration: Trust online and offline. Media and Communication, 6(2), 149-157.

Gruppe gegen Rassismus. (1993). Deutschland, Einig Lagerland. Eine Dokumentation zum staatlichen Rassismus am Beispiel der Unterbringung von Flüchtlingen in Sammellagern nach dem neuen Asylverfahrensgesetz [Germany, united camp country. A documentation of state racism on the example of refugee accommodation in camps after the new asylum law]. (04.154). Archive for Social Movements, Hamburg, Germany.

Hochmuth, K., \& Bispinck, H. (Eds.). (2014). Flüchtlingslager im Nachkriegsdeutschland. Migration, Politik, Erinnerung [Refugee camps in post-war Germany. Migration, politics, memory]. Berlin: Christoph Links Verlag.

Kaun, A. (2016). Crisis and critique. A brief history of media participation. London: Zed.

Kubitschko, S., \& Schütz, T. (2016). Humanitarian media intervention: Infrastructuring in times of forced migration. Spheres Journal for Digital Cultures, 3, 1-14.

Leurs, K. (2017). Communication rights from the margins: Politicising young refugees' smartphone pocket archives. International Communication Gazette, 79(6/7), 674-698.

Leurs, K., \& Smets, K. (2018). Five questions for digital migration studies: Learning from digital connectivity and forced migration in(to) Europe. Social Media + Society, 4(1), 1-16.

Malkki, L. H. (1995). Refugees and exile: From "refugee studies" to the national order of things. Annual Review of Anthropology, 24(1), 495-523.

Malkki, L. H. (1996). Speechless emissaries: Refugees, humanitarianism, and dehistoricization. Cultural Anthropology, 11(3), 377-404.

Marvin, C. (1990). When old technologies were new: Thinking about electric communication in the late nineteenth century. Oxford: Oxford University Press.

Marwick, A. (2013). Status update. Celebrity, publicity, and branding in the social media age. New Haven, CT: Yale University Press.

Mattoni, A. (2012). Media practices and protest politics. How precarious workers mobilise. London: Routledge.

Mattoni, A. (2013). Repertoires of communication in social movement processes. In B. Cammaerts, A. Mattoni, \& P. McCurdy (Eds.), Mediation and protest movements (pp. 39-56). Bristol: Intellect.

McLaren, M. (2010). "Out of the huts emerged a set- 
tled people": Community-building in West German refugee camps. German History, 28(1), 21-43.

Neubauer, M. (1995). Die Unterbringung und Wohnsituation von Flüchtlingen in der Bundesrepublik Deutschland [Accommodation and living conditions of refugees in the Federal Republic of Germany; Unpublished doctoral dissertation]. University of Cologne, Cologne, Germany.

Pickard, V., \& Yang, G. (Eds.). (2017). Media activism in the digital age. New York, NY: Routledge.

Refugee Survey Quarterly. (2008). Selection of documents from UNHCR archives. Refugee Survey Quarterly, 27(1), 121-184.

Runder Tisch Hermannsburg. (1994). Ich weiß nicht, ob ich je wieder lachen kann. Bosnische Flüchtlinge in Hermannsburg erzählen [I don't know if I can ever laugh again. Bosnian refugees in Hermannsburg tell their stories]. (04.300). Archive for Social Movements, Hamburg, Germany.

Smets, K. (2018). The way Syrian refugees in Turkey use media: Understanding "connected refugees" through a non-media-centric and local approach. Communications, 43(1), 113-123.

Taylor, C. (2004). Modern social imaginaries. Durham, NC: Duke University Press.

Turner, S. (2016). What is a refugee camp? Explorations of the limits and effects of the camp. Journal of Refugee Studies, 29(2), 139-148.

Twigt, M. (2018). The mediation of hope: Digital technologies and affective affordances within Iraqi refugee households in Jordan. Social Media + Society, 4(1), 1-14.

UnterstützerInnengruppe. (1994). Wir leben hier wie im Gefängnis. 2 Jahre Bezirkssammellager in der Vauban-Kaserne [We live like in prison. 2 years camp in the Vauban-barracks]. (04.500). Archive for Social Movements, Hamburg, Germany.

Wagner, H.-U. (2014). Vermisstenmeldungen im NWDR [Missing persons reports on NWDR]. NDR. Retrieved from https://www.ndr.de/der_ndr/unternehmen/ geschichte/suchdienst101_page-1.html

Wall, M., Otis Campbell, M., \& Janbek, D. (2017). Syrian refugees and information precarity. New Media and Society, 19(2), 240-254.

Witteborn, S. (2014a). Forced migrants, emotive practice and digital heterotopia. Crossings: Journal of Migration \& Culture, 5(1), 73-85.

Witteborn, S. (2014b). Becoming (im)perceptible: Forced migrants and virtual practice. Journal of Refugee Studies, 28(3), 350-367.

Zahedi, A, \& Walterfang, J. (Eds.). (1992). Geschlossene Gesellschaft. Kleine Dokumentation über Flüchtlinge, ZASt Blankenburg bei Oldenburg und die Aktionen Oldenburger Initiativen [Closed society. Small documentation of refugees, ZASt Blankenburg near Oldenburg and the Oldernburg initiatives]. (04.500). Archive for Social Movements, Hamburg, Germany.

\section{About the Author}

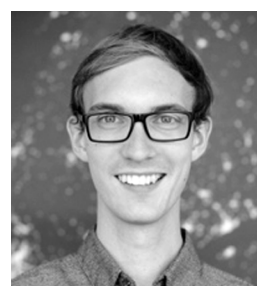

Philipp Seuferling is a Doctoral Student in Media and Communication Studies at Södertörn University, Stockholm, Sweden. He is a graduate from Lund University, Sweden, (MSc) and from Hamburg University, Germany, (BA). His general research interests focus on critical media and migration studies, communication history, and memory studies. 